\title{
IdEe PEDAgogiczNe ANNy FreUd JAKo PRZYKŁad ZASTOSOWANIA ELEMENTÓW PSYCHOANALIZY W EDUKACJI
}

\author{
Paulina Gołaska \\ paulinagolaska@o2.pl
}

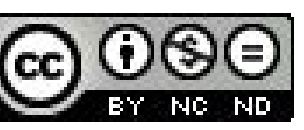

Będąc przez całe życie w cieniu sławy ojca, Anna Freud również i współcześnie pozostaje niedoceniana, czy wręcz pomijana. Często zapomina się, iż rezygnując właściwie z życia osobistego, całkowicie poświęciła się pracy na rzecz dzieci. Inspirację czerpała z wielu obszarów. Głównym przedmiotem jej zainteresowań pedagogicznych stał się przechodzący swój rozkwit na początku XX wieku, progresywizm. Idea wszechstronnego rozwoju stanowiła podstawę jej teoretycznych postulatów wysuwanych względem czytelników, czy słuchaczy, a także wyznaczała kierunek działań jej codziennej egzystencji. Niewątpliwą zasługą Freud stało się sformułowanie założeń "psychoanalitycznie zorientowanej pedagogiki” (psychoanalytically informed pedagogy), której krótki zarys staje się przedmiotem niniejszej pracy.

\section{RELACJA Z OJCEM}

Anna - ulubione dziecko Freuda - od wczesnych lat swojego życia wprowadzana była w świat psychoanalizy, by zgodnie z intencjami ojca, stać się pełnoprawną następczynią i kontynuatorką jego prac. Wypełniając zadanie postawione przez Zygmunta, od samego początku swej działalności naukowej angażowała się przede wszystkim w rozwijanie założeń terapii analitycznej dzieci, która była w tym czasie dziedziną nieco pomijaną. Powodów tych zainteresowań można wskazać wiele. Zjednej strony mogło to być związane z sytuacją osobistą Anny, która jako bezdzietna panna, $\mathrm{w}$ taki sposób realizowała własne potrzeby macierzyńskie. $Z$ drugiej, być może presja związana z byciem córką twórcy psychoanalizy była zbyt duża, aby ją udźwignąć. Prawdopodobnie zatem, w ten pośredni sposób, Anna walczyła o swą autonomię i niezależność wobec niepodważalnego autorytetu ojca. Pomimo ogromnej wagi jaką Freud przywiązywał do okresu dzieciństwa, był on bowiem zwolennikiem analizy dorosłych. Jego technika opierała się na założeniu, że pacjent jest zdolny do swobodnego łączenia treści myśli, które przychodzą mu do głowy podczas sesji terapeutycznej oraz w efekcie samodzielnie wyciaga wnioski na podstawie interpretacji analityka. Wprawdzie w latach 1909 i 1914 Freud opisał dwa przypadki nerwic okresu dzieciństwa, które współcześnie są jednymi z najbardziej popularnych i znanych opisów analizy dziecięcej (jeden znany jako historia Małego Hansa, drugi jako studium Człowieka Wilka), to żadnego nie stworzył na podstawie samodzielnie dokonanej obserwacji. $W$ przypadku pierwszego $z$ nich był-używając terminologii współczesnej - superwizorem ojca chłopca. Człowiek Wilk natomiast - poddany osobistej analizie przez Freuda - trafił do niego jużjako dorosły mężczyzna. Mimo wątpliwości, Freud rozumiał jednak, że ze względu na ów nacisk, który psychoanaliza kładzie na okres wczesnego dzieciństwa oraz możliwości, jakie daje w postaci profilaktyki w zakresie psychopatologii dzieci i młodzieży, może stać się ważną siłą na płaszczyźnie edukacji i wychowania ${ }^{1}$.

Najmłodsza córka była dla ojca postacią niezmiernie ważna, jeśli nie najważniejszą. Dość szybko stała się równorzędnym partnerem naukowych dysput, powierniczką nowych pomy-

\footnotetext{
1 D. P. Britzman, After-Education. Anna Freud, Melanie Klein and Psychoanalytic Histories of Learning, New York 2003, s. 16. 
słów i refleksji. Rola ta przypadła w historii rodziny Freudów niewielu osobom, począwszy od - wymieniając najważniejszych - Minnie Bernays (siostry żony Zygmunta), Wilhelma Fliessa (przyjaciela rodziny) oraz Carla Gustava Junga (ucznia Freuda), a skończywszy właśnie na Annie. To ona, jako jedyna pozostała blisko ojca do samego końca. Ona pielęgnowała go, wyniszczonego przez zbyt późno zdiagnozowany i objęty leczeniem nowotwór żuchwy. Freud natomiast przez długi czas pomagał Annie podejmować ważne decyzje życiowe. Przez wiele lat był jej analitykiem, co z punktu widzenia współczesnej psychoanalizy jest dość poważnym błędem. Miało to swe skutki dla życia zawodowego Anny, bowiem uprawianie rodzinnej analizy stało się poniekąd podstawowym warunkiem funkcjonowania założonej przez nią szkoły.

\section{ŻyCIE ZAWODOWE}

Początki kariery naukowej Anny Freud są bezpośrednio związane z pedagogiką i nauczaniem. Na skutek sugestii ojca, zrezygnowała ze studiów medycznych, a postanowiła zgłębić tajniki wiedzy o edukacji. Latem 1915 r. zdała egzaminy, które pozwoliły jej rozpocząć samodzielną praktykę pedagogiczną². Równocześnie zajęła się tłumaczeniem prac ojca. Pierwszą pracę podjęła w niewielkiej szkole, w której uczyła trzecio-, czwarto- i piątoklasistów. Wielu jej uczniów wspominało później, iż byli pod ogromnym wrażeniem dyscypliny, jaką potrafiła utrzymać zachowując jednocześnie ciepłą i zachęcającą do nauki atmosferę³. Niewiele czasu upłynęło zanim dyrekcja szkoły postanowiła zatrudnić Annę na dłużej, z czego była niezwykle zadowolona. Jej niekwestionowanym sukcesem $\mathrm{w}$ tamtym czasie stało się stworzenie tzw. ochronek dla dzieci - ofiar wojny, które na skutek prowadzonych działań militarnych straciły swoich rodziców lub skazane zostały na samotną egzystencję (z powodu bardzo trudnej sytuacji materialnej, czy zagrożenia bombardowaniami). W 1920 r., z powodu grypy, musiała na stałe zrezygnować z pracy etatowego nauczyciela. Wtedy też zdecydowała, iż resztę życia poświęci psychoanalizie i przenoszeniu jej idei na grunt pedagogiki.

\section{Pedagogika psychoanalityczna. Podstawy teoretyczne}

Anna Freud była zwolenniczką holistycznego i zintegrowanego podejścia do dziecka. Uważała, że specjalizacja w obrębie jednej dziedziny jest niewystarczająca i może przynieść wyłącznie szkody. W swojej pracy wyznawała zasadę, iż każdy profesjonalista, oprócz rozwijania kompetencji w wybranej dziedzinie, powinien przechodzić jednakowy kurs podstawowej wiedzy o dziecku, dotyczącej jego szeroko pojmowanego rozwoju biologicznego i psychologicznego, rodziny, kontekstu społecznego, cywilizacyjnego, itp. . . Często powtarzała, że podczas prowadzenia analizy dziecka należy pamiętać o warunkach, w jakich wzrasta, ale nie tylko w wymiarze aktualnym, lecz obejmującym kilka ostatnich lat z jego życia oraz życia rodziców ${ }^{5}$. Stosując swoje zasady w praktyce, Anna Freud dokonała integracji podejścia psychoanalitycznego i pedagogiki. Omawiając rolę oraz kompetencje nauczyciela, podjęła próbę wskazania w procesie dydaktycznym tych mechanizmów nieświadomości, które dzięki psychoanalizie mogą być dostrzeżone, a następnie zinterpretowane i uświadomione. Pedagogikę pojmowała jako naukę szczegółowo badającą zmiany pozycji ego - od tej bliskiej id do respektującej prawa świata zewnętrznego. Za jej

2 Women's Intellectual Contributions to the Study of Mind and Society. A biography of Anna Freud, http://www.webster. edu/ woolflm/annafreud.html\#anna, 22.07.2009.

3 E. Young-Bruelh, Anna Freud, London 1991, s. 76.

4 R. Edgcumbe, Anna Freud, Gdańsk 2007, s. 218- 219.

5 A. Solnit, A legacy: Anna Freud's Views on Childhood and Development, New York 1997, s. 7. 
cel uznała wspieranie dziecka w rozwijaniu Ja, by umiejętnie radziło sobie z własnymi popędami, respektowało i rozsądnie stosowało przekazywane mu zasady wychowawcze ${ }^{6}$. Zorientowany psychoanalitycznie nauczyciel będzie wolał zaryzykować dając dziecku dużą dozę autonomii, niż stosował przymus tłumiący rozkwit jego samodzielności'. Jednak dawanie dziecku całkowitej swobody nie jest wskazane. Zadaniem pedagogiki jest znalezienie złotego środka pomiędzy osiąganiem i ograniczaniem popędowej gratyfikacji. Jak zauważa autorka, ówczesne metody wychowawcze (pierwsza połowa XX wieku) nie uwzględniały tendencji do unikania przykrości, jaką przejawia dziecko (już w okresie latencji), $\mathrm{w}$ związku z czym popełnionych zostało wiele błędów. Pełna swoboda oraz brak ingerencji ze strony nauczyciela miały umożliwić dziecku wykształcenie złożonej zdolności do sublimacji (która jest określana jako wtórny, dojrzały mechanizm obronny), czyli zaspokojenie popędu w sposób społecznie akceptowany oraz uwzględniający zdolności i zainteresowania jednostki. „(...) dzieci w okresie latencji mogą zwracać większą uwagę na unikanie lęku i przykrości niż na bezpośrednie lub pośrednie zaspokojenie popędu. Jeżeli (...) brak jest kogoś, kto by nimi pokierował, to w wielu przypadkach wybór zajęć, jakiego dokonują zależy nie od ich szczególnych zdolności i umiejętności sublimacyjnych, ale od nadziei na jak najszybsze uwolnienie się od lęku i przykrości. Ku zdziwieniu nauczycieli, w tego typu przypadkach rezultatem wolnego wyboru jest nie rozkwit osobowości, ale osłabienie ego" ${ }^{\prime \prime}$. Zatem postawione zostaje pytanie - na ile zadaniem nauczania jest nakłanianie dzieci do przystosowania się do rzeczywistości, a na ile wolno zachęcać je do odwracania się od niej i tworzenia świata fantazji1 ${ }^{10}$ oraz dążenia do uzyskania natychmiastowej gratyfikacji? W tym miejscu dostrzegalna staje się analogia poglądów Freud i Eriksona, który był przez pewien czas jej uczniem, współpracownikiem, a także pacjentem. Uważał on, iż „,dzieci w tym wieku (latencji - przyp. autora) 1 u b i a być łagodnie, lecz stanowczo zmuszane do przygody odkrywania, że można się uczyć zdobywania rzeczy, o których nigdy by się nie pomyślało, że są tego warte (...). W dyskusjach na ten temat mówi się często, że należy wybrać drogę pośrednią pomiędzy zabawą a praca, pomiędzy dzieciństwem a dorosłościa, pomiędzy edukacją staromodną a postępową. Łatwo jest deklarować wybór takiego kursu, lecz w praktyce jest on często wyznaczany przez potencjalne rafy, a nie przez pożądane cele $^{\prime \prime 11}$. Sam autor odpowiedzi i ostatecznego praktycznego wniosku nie podaje. Anna Freud natomiast próbuje wskazać ramy pedagogicznego oddziaływania na ego mówiąc, iż ogólnym celem wychowania i edukacji powinno stać się pozbycie się zachowań aspołecznych i skierowanie pragnień dziecka na tory norm moralnych istniejących $\mathrm{w}$ społeczeństwie dorosłych ${ }^{12}$. Jednak zarówno zbytnia represyjność, jak i zbytnia swoboda ograniczają dzieci powodując, że „te (...), które w celu zadowolenia swoich rodziców stały się "grzeczne« i społecznie przystosowane, często ku rozpaczy tych samych rodziców przekształcają się w osobowości pełne zahamowańi zubożałe"13.

\section{SzKoła Hietzing. Psychoanaliza w PRAKTyCe Pedagogicznej}

Powyższe, jak i wiele innych zasad Freud wprowadziła w życie w założonej przez siebie i prowadzonej w latach 1927-1932 szkole, dość rzadko opisywanej przez biografów psychoanali-

\footnotetext{
A. Freud, Ego i mechanizmy obronne, Warszawa 2007, s. 104.

A. Freud, Psychoanalysis for Teachers and Parents, Boston 1935, s. 101.

Tamże, s. 105.

A. Freud, Psychoanalysis..., dz. cyt., s. 78.

Tamże, s. 67.

E. Erikson, Tożsamość a cykl życia, Poznań 2004, s. 79.

R. Edgcumbe, Anna..., dz. cyt., s. 68.

R. Edgcumbe, Anna..., dz. cyt., s. 68.
} 
tyczki. Znakomicie wykorzystał to Nick Midgley ${ }^{14}$ pisząc artykuł, prezentujący szczegółowo ten właśnie okres życia Anny. Tekst został uznany za najlepszy w dorocznym konkursie organizowanym przez Fundację Anny Freud (2008). Praca ta stała się nieocenionym źródłem informacji oraz refleksji dotyczących córki Zygmunta Freuda. Pozwala zarazem spojrzeć na psychoanalizę dziecięcą bardziej wszechstronnie i wielopłaszczyznowo.

W swojej szkole, która ze względu na innowacyjność technik i metod miała charakter eksperymentalny, Freud scalała psychoanalityczną oraz edukacyjną teorię i praktykę. Midgley ${ }^{15}$ uważa, że Anna Freud nie była jedyna, która próbowała połączyć te dwie pozornie tak różne dyscypliny, jednak jej szkoła, była zdecydowanie pierwszym takim przedsięwzięciem. Przedstawia on również ogólny obraz edukacji wiedeńskiej w okresie przedwojennym, któremu przeciwstawiała się Freud. Ówczesna niezreformowana pedagogika koncentrowała się na dążeniu do realizacji trzech celów - tworzeniu posłusznych jednostek, akceptowaniu i wykonywaniu zaleceń wyższych i niższych władz, wspieraniu wojska i kościoła ${ }^{16}$. W związku ze zmianami politycznymi, jakie miały miejsce w Wiedniu na przełomie roku $1919 \mathrm{i}$ 1920, nowo ukonstytuowany rząd postanowił zmienić stare, niesprawdzające się w praktyce zasady edukacji. Najbardziej świattym i rewolucyjnym politykiem tamtych czasów, który wprowadził radykalne zmiany był Otto Glöckel, który zasiadł na stanowisku przewodniczącego zespołu specjalistów zajmujących się państwową edukacją w 1922 r. Nowy system uwzględniał potrzeby dziecka, jednak w dużej mierze służył również szerzeniu socjalistycznych idei pomijając rolę jednostki na rzecz społeczeństwa, jako całości.

Jako nauczyciel, Anna wyznawała zasadę holizmu i pajdocentryzmu, umieszczając dziecko w centrum procesu uczenia się - nauczania. „(...) opisała zwięźle trudności w komunikacji między specjalistami, którzy dysponują niewystarczającą wiedzą o innych niż własne sferach działania. Co ważniejsze, podkreślała, że w profesjach ustanowionych na długo przed pojawieniem się psychoanalizy pierwotnie stosowano założenia na temat dzieciństwa, $w$ których nie brano pod uwage wpływu emocji na inne obszary rozwoju. W szkołach panowało przekonanie, że intelekt można rozwijać bez zwracania uwagi na fantazję, lęki i emocje dziecka. Szpitale zajmowały się chorobami ciała, nie biorąc pod uwagę obaw małego pacjenta, jego przywiązania do rodziny czy budzących grozę fantazji na temat uszkodzenia ciała. Sądy usiłowały stać na straży religii, moralności i bezpieczeństwa finansowego dziecka, nie uwzględniając jego potrzeb emocjonalnych"17. Była zwolenniczką i oddanym uczniem Marii Montessori, czego nawet nie omieszkał ująć w swym liście do włoskiej pedagog Zygmunt Freud ${ }^{18}$. Midgley dodaje jednak, iż mimo ogromnej sympatii ze strony Freudów, Montessori nie pochwalała analizy dziecięcej, zarówno jako izolowanej nauki, jak i współdziałającej z pedagogika. Anna Freud jednak nie ustępowała. Od samego początku swojej kariery nauczycielskiej podkreślała, jak ważna jest praktyka, osobista konfrontacja z dzieckiem. Splot sprzyjających okoliczności oraz determinacja sprawiły, że w 1927 r. założyła ona szkołę znaną jako Szkoła Hietzing (nazwa od miejsca położenia placówki), Szkoła Burlingham-Rosenfeld (od nazwisk fundatorek, które stały się nieodłącznymi przyjaciółkami psychoanalityczki) lub jako The Matchbox School (nazwa związana ze specyficznym kształtem i wyglądem budynku) ${ }^{19}$. Anna nigdy nie chciała by placówka stała się masowa, o ogromnym zasięgu. Zależało jej przede wszystkim

\footnotetext{
14 N. Midgley, The 'Matchbox School' (1927-1932): Anna Freud and idea of a 'psychoanalytically informed education', London 2008.

15 Tamże, s. 25.

16 Tamże, s. 26.

17 R. Edgcumbe, Anna..., dz. cyt., s. 235.

18 N. Midgley, The 'Matchbox..., dz. cyt., s. 27.

19 Tamże, s. 32.
} 
na jakości nauczania oraz możliwości objęcia wszystkich uczniów i rodziców terapią psychoanalityczną (najczęściej jako kontynuacja wcześniejszych sesji). Początkowo przeprowadzała ją wraz z innymi analitykami - pedagogami, Augustem Aichhornem oraz Siegfriedem Bernfeldem. Według niej „klasy w szkole powinny być małe, gdyż w tym okresie bardzo ważna jest jakość relacji dziecka z nauczycielem. (...) dobra relacja między dzieckiem a nauczycielem ma szanse powstać w klasach liczących najwyżej dwadzieścia osób" ${ }^{\prime 20}$. Pierwszymi uczniami stali się Walter Aichhorn (syn wspomnianego wcześniej Augusta), Kyra Nijinski (córka słynnej tancerki), Peter Heller (który w dorosłym życiu bardzo precyzyjnie opisał historię szkoły) oraz siostrzeniec Anny, Ernst Halberstadt-Freud (który, zgodnie z tradycją rodzinna, podjął się w dorosłości pracy analitycznej) $)^{21}$. Nauczycielami w Szkole Hietzing mogły stać się osoby, które zgodziły się na przeprowadzanie własnej analizy, często pod okiem Anny. Jednym z bardziej znanych współcześnie pracowników był, wspomniany już wcześniej, Erik Erikson. Czas zajęć każdego ucznia był przeznaczony zarówno na przyswajanie nowych informacji w trakcie systematycznie odbywających się lekcji, jak i na sesje analityczne, które przeprowadzane były codziennie i trwały około godzinę. Jedna z ważniejszych zasad, bardzo restrykcyjnie przestrzegana, zabraniała prowadzącemu dziecko analitykowi bycia jednocześnie jego nauczycielem. Jest to zgodne ze współczesnymi postulatami psychoanalizy w ogóle. Psychoterapia i edukacja dziecka nie mogły być prowadzone przez jedną i tę samą osobę (por. znajdujący się niżej fragment opisujący chłopca poddanego terapii z powodu nawyku robienia głupich $\mathrm{min}^{22}$ - uzyskanie ostatecznej interpretacji mogłoby być niemożliwe, gdyby nauczyciel był równocześnie psychologiem chłopca). Nauczyciele nie mogli również brać udziału w sesjach zespołowego omawiania przypadku, czy spotkaniach superwizyjnych.

W Szkole Hietzing pracowano metodą projektów opracowaną przez Williama Hearda Kilpatrica, ucznia Johna Deweya ${ }^{23}$, która przypomina nieco metodę ośrodków zainteresowań Decroly'ego. W praktyce tematyka lekcji koncentrowała się wokół określonego odgórnie, ogólnego zagadnienia odnoszącego się do środowiska społecznego. Tok lekcji składał się z kilku części - formułowania celów, planowania procesu uczenia się, wykonywania zadań oraz ewaluacji i prowadzony był, w wersji najbardziej optymalnej, w całości przez uczniów, przy minimalnym udziale nauczyciela ${ }^{24}$. Hołdowano swobodzie dziecka i jego ciekawości świata, która miała stać się siłą motywującą do samodzielnej nauki. Erikson ${ }^{25}$ tak opisywał lekcje: „Cała szkoła mogła się stać na jakiś czas światem Eskimosów. Wszystkie przedmioty były wtedy poświęcone ich życiu - geografia, historia, przyroda, matematyka i, oczywiście, czytanie i pisanie". Dorothy Burlingham przedstawiła bardziej dokładny opis zagadnień związanych z tym przykładowym wątkiem - „tematyka tak różnorodna, jak zegary słoneczne, wulkany, oceaniczne prądy, klimat, roślinność i fizyka, (...), starożytne mapy świata, Wikingowie, (...), przemysł wielorybniczy, biologia wielorybów, delfinów, niedźwiedzi polarnych i fok ${ }^{\prime \prime 26}$.

Idea Freud, według której dziecko musi mieć zapewnioną pełną swobodę działania, często spotykała się z protestami i słowami krytyki. Jednak w odpowiedzi na nia, autorka jasno wytłumaczyła, co rozumie pod pojęciem owej wolności. Uznała, że rolą opiekuna jest takie wpływanie

\footnotetext{
20 A. Freud, Psychoanalytic Knowledge and its Application to Children Services, [w:] The writings of Anna Freud, New York 1964/1969, s. 227.

${ }^{21}$ N. Midgley, The 'Matchbox..., dz. cyt., s. 33.

22 A. Freud, Ego..., dz. cyt. (Por. dalej)

23 N. Midgley, The 'Matchbox..., dz. cyt., s. 35

24 Tamże.

25 E. Erikson, J. Erikson, 'Dorothy Burlingham's school in Vienna, London 1980, s. 4.

26 M. J. Burlingham, The Last Tiffany: A Biography of Dorothy Tiffany Burlingham, New York 1989, s. 186.
} 
na dziecko, by zinternalizowało ono jego zalecenia, pojmowało je jako własne i chciało je samodzielnie wykonać. Zatem nigdy nie należy dziecka zewnętrznie przymuszać do zrobienia czegoś wbrew woli, lecz wpływać na nie tak, by w końcu uwewnętrzniło sugestie i polecenia. Tym, co poniekąd motywuje ucznia do podjęcia działania, jest przywiązanie do dorosłego ${ }^{27}$. „Dziecko musi chcieć »coś« zrobić. (...) Nauczyciel musi zatem stać się dla ego ucznia ideałem, z którym dziecko będzie się mogło identyfikowaćn ${ }^{\prime 28}$. Identyfikacja może być przejawiana w różnorodny, będący jednocześnie trudnym do zauważenia, sposób. Dla zobrazowania faktu, jak duży wpływ może mieć dla ucznia osoba nauczyciela i jakie błędy można popełnić nie dostrzegając go, przytoczę fragment książki Freud Ego i mechanizmy obronne ${ }^{29}$ - relację, przedstawioną przez Augusta Aichhorna, który „(...) udzielając konsultacji spotkał się z przypadkiem chłopca (ucznia szkoły podstawowej), (...) zgłoszonego do niego z powodu nawyku robienia głupich min. Wychowawca skarżył się, że kiedy chłopiec był z jakiegoś powodu obwiniany lub ganiony - zachowywał się zupełnie nienormalnie. Wykrzywiał twarz na różne sposoby, co powodowało, że cała klasa wybuchała śmiechem. Wychowawca uważał, iż mogą być dwa powody takiego zachowania: albo chłopiec świadomie robi sobie z niego żarty, albo grymasy twarzy są pewnego rodzaju tikiem. Relacja nauczyciela od razu znalazła potwierdzenie w rzeczywistości, ponieważ chłopiec zaczął robić miny także w czasie trwania konsultacji. Sytuacja wyjaśniła się w momencie, kiedy w gabinecie znaleźli się we trzech: wychowawca, uczeń i psycholog. Aichhorn uważnie obserwując dwóch pozostałych, zauważył, że grymasy na twarzy chłopca były po prostu karykaturą złości wyrażanej przez nauczyciela. Chłopiec bezwiednie naśladował wychowawcę, próbując w ten sposób zapanować nad swoim lękiem wywołanym jego wymówkami. Zidentyfikował się ze złością opiekuna i powtórzył ja, ale w taki sposób, że naśladownictwo nie wyszło na jaw. Przez opisane grymasy uczeń upodabniał się do wywołującego w nim przerażenie obiektu zewnętrznego lub identyfikował się z nim"30. Można się tylko zastanowić, jaki los spotkałby chłopca, gdyby pozostano przy interpretacji mówiącej o celowym i zamierzonym wykpiwaniu nauczyciela.

Szkoła Anny Freud przetrwała tylko kilka lat. Jej najdokładniejsze opisy, wraz w osobistymi wspomnieniami można znaleźć w pracach Petera Hellera. Ocenia on szkołę dość krytycznym okiem, pisząc, iż ,jej niepowodzeniem było niedostosowanie uczniów do rutyny i dyscypliny oraz żmudnego, a czasem bolesnego wysiłku" ${ }^{\prime \prime 31}$, w który gwałtownie zostali wdrożeni po zamknięciu placówki. W swoich późniejszych projektach pedagogicznych (Jackson Nursery, the Hampstead War Nurseries, The Anna Freud Centre Nursery) Freud kładła znacznie większy nacisk na wprowadzanie psychoanalizy w główny nurt edukacyjny, nie zawężając jej wpływu wyłącznie do izolowanych, eksperymentalnych projektów. Swe sukcesy odnosiła z pewnością dzięki elastyczności działań, nieustannej gotowości do stawiania czoła przeciwnościom losu oraz pracowania nad własnym warsztatem edukacyjnym i analitycznym, tak by w jak najbardziej efektywny sposób zająć się małymi pacjentami.

Z punktu widzenia współczesnej psychoterapii Szkole Hietzing można by zarzucić wiele. Z pewnością nie była szkołą idealną. Nauczyciele często różnili się w poglądach dotyczących sposobu nauczania, prowadzenia lekcji, zajmowania się uczniami. Wśród uczniów zdarzały się bójki, wybuchy agresji, bunty. Terapia dziecka i rodziców (którzy sami byli jednocześnie analitykami)

27 R. Edgcumbe, Anna..., dz. cyt., s. 103.

28 N. Midgley, The 'Matchbox..., dz. cyt., s. 37.

29 A. Freud, Ego..., dz. cyt.

30 Tamże, s. 83-84.

31 P. Heller, Anna Freud's Letters to Eva Rosenfeld, Madison 1992, s. 87. 
prowadzona była przez tego samego psychoanalityka. Podobnie analiza nauczycieli, superwizje analityków - nauczycieli i analityków - rodziców. Zdecydowanie brak tu wyraźnej struktury, porządku, może pewnej anonimowości, a przez to zaufania i intymności, niezbędnych w terapii psychoanalitycznej. Jednakże, to właśnie Anna Freud podjęła się pionierskiej próby połączenia dwóch dziedzin, edukacji i psychoanalizy w praktyce. Wskazała tym samym, jak istotne jest holistyczne spojrzenie na dziecko, nie tylko przez zespół specjalistów, ale przez każdego z nich indywidualnie i jak niezbędna jest do tego szeroka wiedza teoretyczna i pragmatyczna.

\section{ROLA PSYCHOANALIZY W PRACY NAUCZYCIELA}

Najważniejsze dla nauk pedagogicznych wnioski zostały przez Freud ujęte w książce Psychoanalysis for teachers and parents (Psychoanaliza dla nauczycieli i rodziców) ${ }^{32}$. W rozdziałach bezpośrednio poświęconych pedagogice, Freud skupia się przede wszystkim na osobie nauczyciela, na jego konfliktach wewnętrznych, motywach i mechanizmach obronnych. Pytania, które nasuwają się po lekturze wymienionych akapitów, są zaskakująco proste, lecz znamienne: Zastanów się, dlaczego chcesz nauczać? Jak się zachowujesz, gdy nauczasz? Co myślisz o swoich uczniach? Tym samym, Freud wskazuje na niezwykle istotną rolę, jaką w procesie uczenia się - nauczania, który zawsze jest procesem interakcji dwóch podmiotów - nauczyciela i ucznia - pełnią mechanizmy nieświadomości. Postuluje konieczność przeprowadzania przez pedagogów obserwacji, prób analizy i interpretacji (pod okiem specjalisty analityka) własnej psychiki. Freud uważa, że w klasie szkolnej, bardzo często można spotkać się z psychoanalitycznym mechanizmem przeniesienia, polegającym na rzutowaniu własnych nieświadomych myśli, uczuć powstałych w okresie dzieciństwa na inna, niemającą związku z pierwotną sytuacja, osobę. Nauczyciel zatem nie tylko musi być świadomy możliwych przeniesień (pozytywnych, jak i negatywnych) ze strony uczniów, ale przede wszystkim powinien zaakceptować istnienie własnych nieświadomych konfliktów rzutowanych na dzieci. „,...) dla nauczyciela klasa szkolna jest tak znajomym miejscem, że z łatwością wzbudza i ożywia dziecięce wspomnienia (wspomnienia rozumiane jako zarówno świadome, jak i przede wszystkim nieuświadamiane $\left.{ }^{33}\right)$. (...) przeniesienie wpływa na to, jak nauczyciele słuchająi reagują na uczniów oraz na to, jak uczniowie słuchają i reagują na nauczycieli”34. Trudności mogą wystąpić wtedy, gdy nauczyciel nie docenia wagi i nie poddaje analizie własnej nieświadomości, która kształtuje pedagogikę przez niego tworzoną ${ }^{35}$. Według Anny Freud analiza jest etycznym obowiązkiem pedagoga, który powinien zrozumieć własne konflikty i motywy, by móc ograniczyć ich wpływ na uczniów. Elementem decydującym dla wyboru obiektu przeniesienia może być cokolwiek - gest, mimika, ton głosu, specyficzny przedmiot $^{36}$. Nie można w sposób pewny przewidzieć, który uczeń wywoła daną reakcję, czy stanie się obiektem pozytywnych, czy negatywnych emocji. Dorothy Britzman, opisując własne przemyślenia dotyczące mechanizmu przeniesienia w procesie uczenia się - nauczania, sugeruje, iż tego typu problemy i trudności pracy nauczyciela powinny być omawiane już na etapie studiów pedagogicznych - podczas zajęć ze studentami. Wykształcony w dziedzinie psychoanalizy wykładowca powinien starać się zachęcić swoich słuchaczy do prowadzenia systematycznej obserwacji własnych działań pedagogicznych, poczynając od pogłębionego zastanowienia się nad

32 A. Freud, Psychoanalysis..., dz. cyt.

33 Przyp. autora.

34 D. P. Britzman, A. J. Pitt, Pedagogy..., dz. cyt., s. 117.

Tamże.

36 J. Laplanche, J. B. Pontalis, The language of psychoanalysis, London 1988, s. 120. 
czynnikami, które mogły wpłynąć na wybór kierunku studiów, a kończąc na wyobrażeniach prowadzonej przez siebie w niedalekiej przyszłości klasy. W trakcie studiów, które obfitują przecież w liczne i różnorodne praktyki studenckie (godziny spędzone w przedszkolach, szkołach, ośrodkach opiekuńczo- wychowawczych i wielu innych instytucjach sprawujących pieczę nad dziećmi i młodzieża), planujący pracę w zawodzie student ma niezwykle wiele możliwości analizy własnych reakcji, ożywających emocji, przychodzących do głowy myśli, czy wspomnień. Każdy z tych elementów można potraktować jako symbol, reprezentacje nieświadomości, który w bardziej lub mniej ukryty i zamaskowany sposób wskazuje na te wydarzenia, te sytuacje, które w jego dzieciństwie wywarły ogromny wpływ i mogą determinować jego pozornie świadome i dowolnie podejmowane działania pedagogiczne. Autorka uważa, że jeśli nauczyciel nie przepracuje własnych konfliktów w nieświadomości, może na przykład (nie zdając sobie z tego sprawy!) dążyć do tego, by uczniowie popełniali błędy - chcąc czuć się potrzebnym, docenianym i kompetentnym poprawiając je ${ }^{37}$.

\section{STUDIUM PRZYPADKU. ZAKOŃCZENIE}

Podsumowanie stanowić będzie opis doświadczeń pewnej guwernantki, znajdujący się w książce Freud, który trafnie ilustruje powyższe wnioski oraz stanowi przeciwwagę dla nasuwających się ewentualnie wątpliwości, co do ich słuszności: „,Znakomita nauczycielka, która rozpoczęła swoją karierę zawodową w osiemnastym wieku, w związku z trudną sytuacją rodzinną została zmuszona do opuszczenia domu i podjęcia pracy guwernantki trzech chłopców. Średni z nich przejawiał pewne trudności w uczeniu się. Zbyt wolno przerabiał przeznaczony dla niego materiał, był lękliwy, zdystansowany i nie tak bystry jak jego bracia; $w$ swej rodzinie traktowany podrzędnie, pomijany, często z negatywnym skutkiem porównywany do swego utalentowanego rodzeństwa. Nauczycielka poświęciła całą swą energię i włożyła wiele wysiłku w edukację chłopca, co w krótkim czasie przyniosło wspaniałe rezultaty. Chłopiec bardzo przywiązał się do swej opiekunki, był jej oddany jak nikt inny wcześniej, stał się szczery i pełen sympatii dla niej. Jego zainteresowanie lekcjami znacząco wzrosło i dzięki pracy kobiety udało mu się nadrobić zaległe treści osiaggając tym samym poziom adekwatny dla swego wieku. Rodzice byli bardzo dumni ze swojego dziecka, któremu wcześniej rzadko okazywali swe względy. Często poświęcali mu swój czas i uwagę, jego relacje z braćmi również uległy poprawie, aż w końcu chłopiec objął pozycję najbardziej wartościowego członka rodziny. W obliczu rodzinnego szczęścia, nastapiły jednak pewne komplikacje. Nauczycielka, której chłopiec zawdzięczał swój sukces, nie potrafiła się z nim porozumieć. Nie okazywała mu więcej miłości, nie potrafiła z nim współpracować. W końcu opuściła dom, w którym była niezmiernie doceniana, z powodu dziecka, które na początku stało się głównym obiektem jej zainteresowania. Terapia psychoanalityczna, której się poddała piętnaście lat później z powodów związanych z praca, ujawniła jej prawdziwe powody, dla których nie sprostała zadaniu dalszego kształcenia chłopca. W swoich wyobrażeniach rodzinnego domu i dzieciństwa przedstawiała siebie jako niekochane dziecko - opisując swoją sytuację w podobny sposób, w jaki przyszło żyć wcześniej wspomnianemu chłopcu, kiedy rozpoczęła z nim pracę. Na podstawie podobieństwa, jakie dostrzegała zidentyfikowała się z chłopcem. Całą swoją miłość i troskę, jaką przejawiała w stosunku do niego wykorzystała, by poczuć: »Tak właśnie powinnam być traktowana, bym mogła w życiu zostać kimś«. Sukces, który osiągnęła w pracy z chłopcem, zniszczył możliwość dalszej identyfikacji. Sprawił, że chłopiec stał się

37 D. P. Britzman, After-Education..., dz. cyt., s. 91. 
niezależny i samodzielny i nie mógł dłużej stanowić obiektu, z którym utożsamiała się kobieta. Wrogie uczucia wobec niego miały swoje źródło w zawiści, jaką czuła; nie mogła nie zazdrościć mu sukcesu, którego w swoich oczach ona nigdy nie doświadczyła" ${ }^{38}$. Można pomyśleć, że całkiem dobrze, iż owa nauczycielka nie przeszła analizy wcześniej. Być może nie doszłoby wtedy do tak spektakularnego sukcesu pedagogicznego. Jednak co z tymi dziećmi, które nie mają tyle szczęścia, by ożywić dawne, ważne konflikty i wzbudzić tym samym pozytywne uczucia i fantazje? Co z tymi, którzy są źródłem nieprzyjemnych uczuć i nieuświadamianych wspomnień? Co z tymi, którzy są pedagogom obojętni? Psychoanaliza nie jest środkiem pozwalającym poradzić sobie z wszystkimi trudnościami, jakie napotyka w swojej pracy nauczyciel. Być może wręcz powiększa ich liczbę, wzbudzając liczne pytania i nie dając na nie odpowiedzi. Umożliwia jednak odkrycie tego, co rzeczywiście kieruje ludzkim zachowaniem, co leży u podłoża pragnienia kontaktu z drugim człowiekiem - w tym wypadku uczniem. Skłania do samodzielnych poszukiwań konfrontując z nieodgadnionymi częściami psychiki. Poszerzając pole świadomości, dopuszczając do głosu konfliktową stronę ludzkiej natury, pozwala lepiej poznać siebie. To jedyny sposób, by prawdziwie poznać naszych uczniów.

\section{BibLIOGRAFIA}

Britzman D. P., After-Education. Anna Freud, Melanie Klein, and Psychoanalytic Histories of Learning, New York 2003. Britzman D. P., Pitt A. J., Pedagogy and Transference: Casting the Past of Learning Into Presence of Teaching, Ohio 1996. Burlingham M. J., The Last Tiffany: A Biography of Dorothy Tiffany Burlingham, New York 1989.

Edgcumbe R, Anna Freud, Gdańsk 2007.

Erikson E., Tożsamość a cykl życia, Poznań 2004.

Erikson E., Erikson J., Dorothy Burlingham's school in Vienna, New York 1980.

Freud A., Psychoanalysis for Teachers and Parents, Boston 1935/1960.

Freud A., Burlingham D., Infants without Families and Reports on the Hampstead Nurseries 1939-1945, New York 1944/1974.

Freud A., Psychoanalytic Knowledge and its Application to Children Services, [w:] The writings of Anna Freud, New York $1964 / 1969$.

Freud A., Ego i mechanizmy obronne, Warszawa 2007.

Heller P., Anna Freud's Letters to Eva Rosenfeld, Madison 1992.

Laplanche J., Pontalis J. B., The language of psychoanalysis, London 1988.

Midgley N., The 'Matchbox School' (1927-1932): Anna Freud and the idea of a 'psychoanalytically informed education', London 2008.

Solnit A., A legacy: Anna Freud's Views on Childhood and Development, New York 1997.

Young-Bruelh E., Anna Freud, London 1991.

\section{Netografia}

Women's Intellectual Contributions to the Study of Mind and Society. A biography of Anna Freud, http://www.webster.edu/ woolflm/annafreud.html\#anna, 22.07.2009.

\section{Słowa kluczowe}

Anna Freud, psychoanaliza, nieświadomość, proces uczenia się - nauczania, pedagogika psychoanalityczna

\section{STRESZCZENIE}

Autorka podejmuje próbę wskazania charakterystycznych dla teorii psychoanalitycznej mechanizmów w procesie uczenia się - nauczania, ujętych po raz pierwszy w tym kontekście przez Annę Freud. Elementem integralnym pracy jest biografia pionierki psychoanalizy dziecięcej,

38 A. Freud, Psychoanalysis..., dz. cyt., s. 106-109. 